\title{
Exploring the Origins of Creating Shared Value in the CSR Literature
}

\author{
Jose L. Camarena-Martinez ${ }^{1}$, Beatriz Ochoa-Silva ${ }^{2} \&$ Teodoro R. Wendlandt-Amezaga ${ }^{2}$ \\ ${ }^{1}$ Organizational Management, Sonora Institute of Technology, Ciudad Obregon, México \\ ${ }^{2}$ Department of Administrative Sciences, Sonora Institute of Technology, Ciudad Obregon, México \\ Correspondence: Beatriz Ochoa Silva, Department of Administrative Sciences, Sonora Institute of Technology, 5 \\ de Febrero 818 Sur, Col. Centro, Ciudad Obregón, Sonora, México. Tel: 52-644-410-9000 ext. (2917). E-mail: \\ Beatriz.ochoa@itson.edu.mx
}

Received: October 13, 2016

Accepted: November 3, $2016 \quad$ Online Published: November 20, 2016

doi:10.5539/ijbm.v11n12p97

URL: http://dx.doi.org/10.5539/ijbm.v11n12p97

\begin{abstract}
This article seeks to provide theoretical evidence to trace the origins of the idea behind the model Creating Shared Value (CSV), proposed by Porter and Kramer in 2011, whose originality is questioned according to a recent debate in the literature of corporate social responsibility (CSR) by authors such as Crane, Palazzo, Matten and Spence. Based on the latter, the article provides an analysis of perspectives and models in modern literature CSR within the creating shared value approach (CSV), meaning the value for the company and the value to society. The results indicate that some assumptions on which shared value is based may implicitly be suggested in works prior to the date of publication of the CSV model, however it discussed that this may be due to the variegation view of CSR literature.
\end{abstract}

Keywords: creating shared value, corporate social responsibility, CSR, literature review

\section{Introduction}

During the development of the literature of corporate social responsibility (CSR) key questions raised by academics in the area such as how do entrepreneurs perceive CSR? (Holmes, 1976) What benefits do companies obtain from their CSR activities? (Carroll \& Shabana, 2010) Who are the priority actors to whom the company should respond? (Mitchell, Agle, \& Wood, 1997) or what is the relationship between financial performance and CSR? (Margolis, Elfenbein, \& Walsh, 2007).

The above and other questions have invariably generated theoretical debates. However, within these there is a recent one that has attracted particular attention and which seeks to address the following question: In what conditions does CSR generates value for the company? In order to answer the above, the proposal of Michael Porter and Mark Kramer (2011), the creation of shared value (CSV) arises, and according to the authors is the best alternative for companies, which they consider as the evolution of the capitalist model.

Porter and Kramer (2011) define the shared value creation as "... policies and operating practices that enhance the competitiveness of a company as well as the economic and social conditions in the communities in which it operates." (p.6). The authors argue that the CSV is the next step the classic social responsibility should take, which is criticized as being an attempt of companies to generate a good image, but that does not necessarily produce strategic benefits to organizations. Creating shared value then seeks to fill the existing gap of how to generate economic value for the company (Maltz, Thompson, \& Ringold, 2011) while value to society is given (Pirson, 2012) from activities of social responsibility with a strategic approach.

Creating shared value is a concept that has generated controversy. For example, it has received positive reviews (Bosch-Badia, Montllor-Serrats, \& Tarrazon, 2013; Moon, Pare, Yim, \& Park, 2011), yet it has been criticized as theoretical concept (Aakhus \& Bzdak, 2012; Beschorner \& Hajduk, 2015; Crane, Palazzo, Spence, \& Matten, 2014); questioned as business idea (Baraka, 2010); analyzed in the practice of companies (Brown \& Knudsen, 2012; Maltz \& Schein, 2012) and it has even been considered in the media with different opinions (Denning, 2011; Donaldson, 2014; Dyllick, 2014; Epstein-Reeves, 2012; Schumpeter, 2011). The above mentioned implies that the proposal of CSV is a relevant topic in the literature of business administration and as such worth studying (Dembek, Singh, \& Bhakoo, 2015). 
This article focuses on the theoretical debate between Porter and Kramer $(2011,2014)$ and Crane, Palazzo, Spence and Matten (2014) specifically regarding to the originality of the central idea of the CSV concept. According to its detractors, creating shared value is similar to existing concepts in literature: "Porter and Kramer present the CSV as a novel contribution; however, its basic premises have a surprising similarity to existing concepts of CSR, such as stakeholders' management, and social innovation" (Crane et al., 2014, p. 34).

Additionally, the lack of recognition of the authors who had suggested the compatibility between social and economic benefits in the literature of CSR is questioned: "Porter and Kramer neither recognize that their ideas about the simultaneous creation of economic and social value for multiple stakeholders have already been well developed in the literature" (2014, p. 34).

According to the above debate, the goal set for this article is to provide theoretical evidence in order to justify the criticism of Crane and colleagues regarding the originality of the idea behind the CSV concept coined by Porter and Kramer (2011). Based on the latter, a literature review is proposed so that perspectives and models of CSR are researched, in which the general idea of shared value will be analyzed and implicitly searched for, that is the value creation for the company and society.

\section{Method}

In order to achieve the objective, theoretical information was sought on corporate social responsibility in bibliometric and literature reviews, using databases such as Web of Science (WoS), Scopus and Proquest, demarcating the search to the period between 1953-start date of the CSR modern literature-and 2011.

The information was delimited and organized chronologically for three reasons: First, because the goal is to provide evidence that the idea of creating shared value was already working before the publication of the article by Porter and Kramer in 2011. Second, because the chronological order provides an ideal way to explore the evolution of the concept of shared value from the first contributions of modern literature in 1953 CSR (Carroll, 1999), to more recent concepts. Third, because there is evidence of previous review work of literature that have used this scheme to structure the analysis (Carroll, 1999, 2008; Frederick, 2006; Moura-Leite \& Padgett, 2011; Wang, 2015).

To meet the objective of this research, the article is divided into three sections. In the first, it briefly describes the concepts of corporate social responsibility, creating of shared value and stakeholders. In the second, CSR perspectives and models are analyzed chronologically and it is briefly indicated where the idea could be located under the shared value approach for stakeholders. Finally, in the third part, final considerations are presented, where the results obtained are synthesized and a conclusion is given based on the findings.

\section{Definition of Central Concepts}

In this section the central concepts to this literature review are introduced; corporate social responsibility, whose background is analyzed chronologically from the past half century. Creating shared value, which is analyzed from the three levels perspective proposed by Porter and Kramer (2011). Finally, the stakeholder approach developed by Freeman (1984) which argues that groups of interest are located in two types of organizational environment.

\subsection{Corporate Social Responsibility}

The beginnings of corporate social responsibility (CSR) usually date back to the United States of America of half the XX century. However, there is evidence a century before of business activities such as philanthropy, welfare at work and service, which are concepts that predate the contemporary CSR, in countries such as Britain, India and Japan (Husted, 2015).

However, for purposes of this article, the birth of the CSR in the work of Howard Bowen 1953 Responsibilities of the business man is considered, as from its publication it is said that the modern literature of corporate social responsibility (Carroll, 1999) begins. The work of Bowen is relevant because it suggests the existence of compatibility between the objectives of employers and society, "the obligations of businessmen to pursue those policies, to make those decisions, or follow lines of desirable action in terms of objectives for society." (1953, p. 6).

According to Frederick (2006) in the fifties the main ideas around CSR resided in: (a) corporate administrators and trustees; (b) balanced representation on corporate resources and (c) philanthropic support for good causes. Meanwhile, in the 60s, CSR was characterized by the emergence of schools of thought as the vision of corporate managers as ambassadors for the public welfare, referring to the voluntary acceptance of public responsibilities by business leaders. 
The seventies, according to Moura (2011) were a period during which business managers applied a traditional management in order to address CSR issues; most of them following the model of self-interest. While in the next decade, commercial and social interests approached and businesses became more sensitive to interested parties or stakeholders.

Following Moura (2011), from the 90s onwards, the study of CSR has moved away from an ethical orientation to a performance one, and the level of analysis changed from macro social level to the organizational level. In addition to this, the author argues that the attention to the relationship between CSR and the corporate financial performance was transformed over time in the academic field, going from irrelevant to a close association.

During the development of CSR literature, various definitions of it have emerged (Dahlsrud, 2008), therefore it is relevant for purposes of this article to specify a single definition that serves as a thread for the intended analysis. Considering the above, the definition of CSR proposed by Aguinis (2011) "The organizational actions and policies specific of the context taking into account expectations of stakeholders and the triple result in economic, social and environmental performance" (p. 855) is taken. The inclusion of the term stakeholder somehow helps to specify before whom the company is responsible for, since the term of society is somewhat ambiguous.

Meanwhile, to frame the part of the value for companies and unify the criteria to perform the analysis, it was decided to use the version of Burke and Logsdon "...easily measurable flow of economic benefits that the company expects to receive" (1996, p. 499). Definition that lies in the context of social responsibility.

\subsection{Creating Shared Value}

Porter and Kramer (2011) introduce their proposal to create shared value as a theoretical alternative that incorporates implicitly the economic value for the company and the social value, since in general terms shared value refers to the establishment of a win-win relationship regarding the organization and society. The model in question arises from the criticism of the authors towards traditional CSR efforts, which are neither necessarily for the benefit of the company nor are linked to the strategic planning of organizations.

The concept of shared value could be traced back to the term of co-creation of value, which according to Corsaro (2014) in the early 2000, Prahalad and Ramaswamy (2000) suggested that the place for value creation moved from the department of the company for research and development to interaction between the company and customers, creating a stream of research later called co-creation of value.

Retaking the model Porter and Kramer (2011), creating shared value can be generated from three perspectives or levels. The first level has to do with the re-design of new products and services, which should be aligned with issues or social problems, this way it can meet a new need, positively impacting society at the same time as the company generates profits.

The second level is based on the internal management of the value chain, which can be redefined in terms of innovation by reducing costs, minimizing consumption of energy and process optimization, taking advantage of externalities that the chain produces.

Finally, the third level, the development of local clusters (choice of local suppliers and/or needy communities) can help increase the value for the target communities, such as job creation and stimulate the economy of a region while companies can obtain unique benefits by generating synergy with the organizational strategy. According to Porter, Hills, Pfitzer, Patscheke, and Hawkins (2012), these three levels of shared value can bring various benefits for both the company and society, examples are seen in Table 1.

It can be seen that the term society is generally used to refer to various actors in the organizational environment, for example, residents of local communities where the company operates, school students, environmentalists, users of hospitals that could be even part of the same company. This raises a key question for companies, who is accountable? Who are the priority actors for the company?

On this point, Carroll (1999) suggests to reconcile the concept of society with the term stakeholder (interest group) proposed by Freeman (1984) to put "names and faces" to the society. This somehow to specify to who is responsible the company. Additionally, Clarkson (1995) proposes separating the affairs of the society and issues of stakeholders depending on the level of analysis. For the institutional level the author argues that social problems are seen, while for the organizational level the problems of interest groups are analyzed. 
Table 1 . Results for the company and society by level of shared value

\begin{tabular}{|c|c|c|}
\hline Shared value levels & Business results & Results for society \\
\hline \multirow[t]{2}{*}{ Re-design of products and services } & Increased return & Improved patient care \\
\hline & Increased market share & $\mathrm{CO} 2$ emission reduction \\
\hline \multirow[t]{2}{*}{ How to set unmet needs incentives increase in return and profits } & Market growth & Improved nutrition \\
\hline & Increased profitability & Improved education \\
\hline \multirow[t]{2}{*}{ Redefinition of productivity in the value chain } & Improved productivity & Reduced power usage \\
\hline & $\begin{array}{l}\text { Reduction in logistics and } \\
\text { operating costs }\end{array}$ & Reduction in water usage \\
\hline \multirow{3}{*}{$\begin{array}{l}\text { How to better manage internal operation increases productivity and } \\
\text { reduces risks }\end{array}$} & Secured supply & Reduction in materials \\
\hline & Improved quality & Development of labor skills \\
\hline & Improved profitability & $\begin{array}{l}\text { Improvement in the income of } \\
\text { employees }\end{array}$ \\
\hline \multirow[t]{3}{*}{ Encourage the development of local clusters } & Costs reduction & Improved education \\
\hline & Secured provision & Creation of new jobs \\
\hline & distribution & Improved health \\
\hline \multirow{3}{*}{$\begin{array}{l}\text { How changing social conditions outside the company results in growth } \\
\text { and productivity improvements }\end{array}$} & infrastructure & \\
\hline & $\begin{array}{l}\text { Improved access to the } \\
\text { workforce }\end{array}$ & Increased revenue \\
\hline & Increased profitability & \\
\hline
\end{tabular}

Note. Adapted from Porter, Hills, Pfizer, Patschke and Hawkins (2012).

For the above reasons, the incorporation of the term stakeholder for the analysis of the concepts and models of social responsibility seeking to clarify the value attributed to the company is deemed necessary. However, in which interest groups is perceived the social value? Therefore, it is considered appropriate to include a brief history of the concept and delimit the interest groups.

\subsection{Stakeholders}

A relevant and associated with corporate social responsibility topic has been the stakeholder approach, which states that organizations must take into account the stakeholder groups with direct and indirect interests in and by the organization. In words of Freeman (1984), this term may refer to "... any group or individual that affects or is affected by the achievement of organizational objectives." (p. 46).

These groups may be individuals or groups that can influence an organization, their resources or their outputs (Bryson, 1995), who have the power to negotiate and change the strategic future of an organization (Eden \& Ackermann, 1998), which depend on achieving organizational objectives to fulfill their own or vice versa (Scholes \& Johnson, 2002) or simply that affect or will affect the strategies of the organization (Nutt \& Backoff, 1992).

Stakeholder groups can be varied depending on the operation of the organization. However, Freeman (1984) classifies them according to their location in the organizational environment in the internal and external dimensions. In the internal environment there are 1 shareholders, customers, employees and suppliers. Meanwhile, in the external environment actors such as governments, competitors, the media, special interest groups, environmentalists and consumer advocates are identified; they can be seen graphically in Figure 1. 


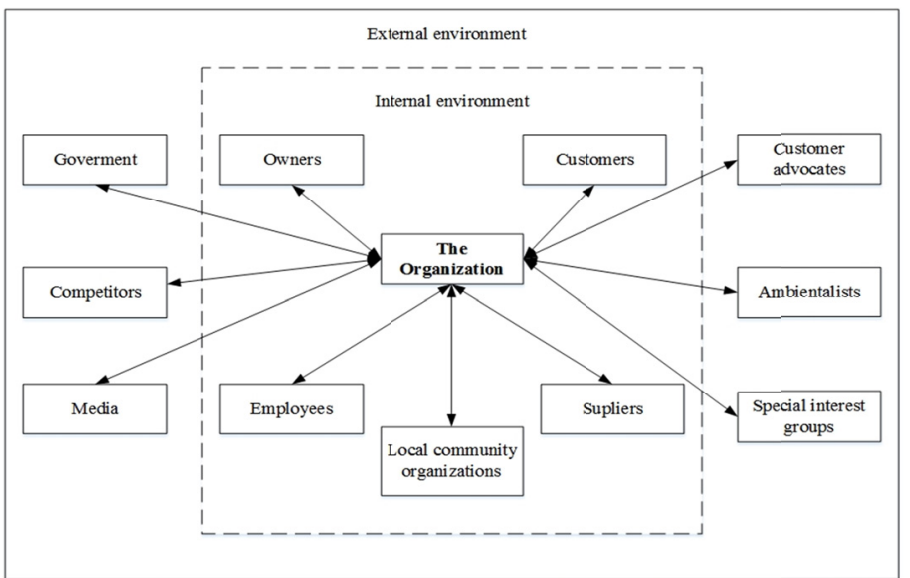

Figure 1. Stakeholder groups according to internal and external organizational environments (Freeman, 1984)

The analysis of CSR perspectives and models will take Freeman's stakeholder approach (1984) as reference, meaning the actors in the organizational environment that receive the social value (Clarkson, 1995). Additionally, note that the stakeholder approach has been used by scholars to define the CSV construct (Dubois \& Dubois, 2012; Maltz \& Schein, 2012; Maltz et al., 2011; Shrivastava \& Kennelly, 2013; Verboven, 2011) which allows to relate the two concepts.

\section{Analysis of Theoretical Perspectives in Modern Literature of CSR}

Social responsibility has existed since the businessmen began to worry about more than their profits. An example is 1917 Henry Ford's vision of the company as an entity “... to make it possible for everyone concerned, to earn money and use it, give employment, and send out the car where people can use it...and incidentally to make money ...The business is a service not a bonanza" (Lewis, 1976). Therefore, Ford thought of his company as a means of providing value to its customers and employees as a priority and make profits as a result. Examples like this can be found if one explores in depth the history of corporate social responsibility (Heald, 1970; Husted, 2015).

However, as mentioned in the introduction of this article, the analysis focuses from the modern era of literature of CSR with the publication of the work of Bowen (1953), in which the author's main idea is that the companies have power and that their actions impact on the lives of the population in several ways. Therefore, organizations have a commitment to use that power responsibly.

From the cited work of Bowen, a number of important contributions to the theory of CSR from which previous revisions already exist (i.e. Carroll, 1999; Moura, 2011). However, the objective of this article requires the analysis of those contributions that according to their content directly or indirectly involve the creation of shared value between business and society (see Table 2). The following are the relevant documentary research findings, according to the purpose of this article.

Table 2. CSR perspectives in relation to shared value

\begin{tabular}{ll}
\hline Author & CSR perspective concerning the shared value \\
\hline Levitt (1958) & CSR only if it is profitable for the company \\
Frederick (1960) & Socioeconomic welfare \\
McGuire (1963) & Obligations to shareholders and other interest groups \\
Davis \& Bloomstrom (1966) & Taking into account the needs and interests of other groups in addition to economic and technical needs \\
Friedman (1970) & CSR only if it is profitable for the company \\
Steiner (1970) & Benefiting from CSR activities \\
Johnson (1971) & CSR should address multiple interests and may add benefits to the company \\
CED (1971) & It takes into account business and other groups' needs. \\
Jones (1980) & Obligations of the company to different groups other than shareholders \\
Drucker (1984) & Economic benefits from CSR activities \\
Carroll (1999) & Compatibility between economic benefit and social benefit \\
Jensen (2000) & CSR as long as it is in the interests of the company \\
\hline
\end{tabular}


Lantos (2001)

Milliman, Ferguson \& Sylvester

(2008)

Aras \& Crowther (2009)

Werner (2009)

Note. Own elaboration.
CSR that helps meet business objectives

Social and economic benefits at the same time

They consider multiplicity of interests, including financial services of the company and stakeholders CSR as a source of innovation and competitive advantage

For Levitt (1958) "Corporate welfare is only meaningful if it makes economic sense-and it is rare when it happens. But if something does not make economic sense, either it is sentimentalism and idealism, they should not enter the door." (p. 42). What stands out from this position is that the idealistic activities such as social responsibility just have sense as long as they have economic purposes, which is a premise of the creation of shared value: mutual benefit between business and society, as if only philanthropic activities are carried out outside the context of the organization, the value for the company will be minimal.

Years later, Frederick (1960) raised the idea of shared value in his outlook on corporate social responsibility, "the means of production of the economy should be used so that the production and distribution should improve the overall socio-economic welfare." (p. 60). That is, that economic objectives and thus the resources used for such purposes should be used towards a dual social and economic benefit. This equates to redefining productivity in the value chain, as it suggests management of the means of production to save resources and reduce environmental impact.

Around the same time, McGuire (1963) argued that companies should address issues of other groups of relevant actors besides shareholders such as political scope, community, education and workers. Some of these elements are used as examples of favorable results in the shared value model (Table 1).

Another important perspective was that of Milton Friedman, who in 1970 accepted the integration of some of the social demands in the company on the condition that they turned out profitable in the long term. For him, social actions are acceptable only if they are justified in self-interest of companies (1970). One might say that such an approach laid the foundation for developing the idea of shared value, since according to this, organizations must see social activities as an investment and not an expense, which means, to be profitable in the future.

A year later, 1971, the Committee for Economic Development of USA(CED) published a document which defined the CSR through the articulation of three circles representing three stages of objectives to be met in order of priority. The proposed model in the aforementioned document can be seen in Figure 2 .

The model is made up of three circles, which correspond to a level of responsibility that corporations should assume according to the CED. The inner circle establishes the basic responsibilities to achieve efficient economic function. The second one involves the practice of economic function with the concern of social priorities and bringing awareness of the environment. While the third circle represents the most emerging responsibilities that at certain times companies must take in order to be more involved in the betterment of the society.

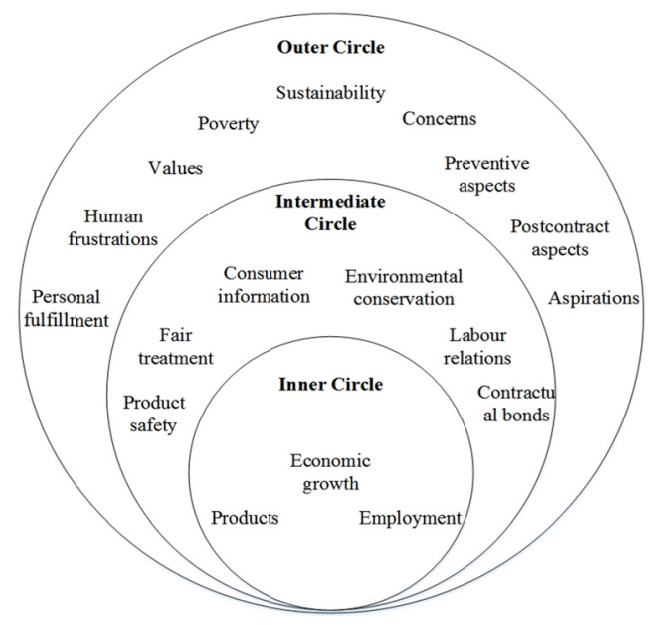

Figure 2. Relationship of the defining circles of corporate social responsibility according to the three levels suggested by the committee for economic development (CED, 1971) 
It is inferred that according to the perspective of the CDE, the priority for companies lies in economic growth, which translates as the financial value for its shareholders. But also the products and employment are highlighted, which concern customers and employees respectively. That is, that these three interest groups, located in the internal environment proposed by Freeman (1948) are the highest priority and together constitute a win-win relationship between business and society, as customers and employees are part thereof. Complementing the above idea, in the middle circle are located other aspects concerned with customers and employees, with the exception of the environmental conservation element, which regards as an external environment stakeholder according to Freeman. Finally, in the external circle, ethical and philanthropic social responsibilities (Carroll, 1979) are included, which strengthen the chances of a company to positively affect their environment.

In the same year, George Steiner brought his vision of corporate social responsibility, for him, all business are primarily economic institutions, but they also have responsibilities to society. However, companies can meet those responsibilities without incurring costs as well as profiting (1971). This clearly indicates compatibility between the financial objectives of the company and those of social nature, and the author goes further to suggest that it is possible to profit by meeting social obligations, as stated by the CSV model.

Meanwhile, Johnson (1971) argued that a socially responsible company is one “... whose managerial staff balances a multiplicity of interests. Instead of striving only for greater profits for its stockholders, a responsible enterprise also takes into account employees, suppliers, dealers, local communities, and nation" (p .50). With this contribution a ratification that companies should consider more actors who have interests in the company is observed, but the author goes even further and includes the nation as a potential objective of value creation. In addition to this, Johnson added that "corporate social responsibility requires the implementation of social programs to add benefits to your organization" (p. 54). This perspective already interpreted CSR as a way to maximize profits, premise of the creation of shared value.

In the eighties, Jones (1980) stated that CSR is a set of obligations to other social groups as well as shareholders and cited as an example to customers, employees, suppliers and surrounding communities. Again, an idea of corporate social responsibility that addresses the needs of the partners to make profits but in turn, the obligation of the company to respond to other groups belonging to the organizational environment is perceived.

Another important contribution above the idea of shared value was proposed by Drucker (1984), who advocated converting social problems into business opportunities. This is similar to what is established in the first level of shared value, the re-design of products and services, which aims to satisfy social needs turning them into business opportunities. According to Drucker, social problems could be transformed into productive capacities and human competencies. This is linked to the second level model of Porter and Kramer (2011), productivity in the value chain, because the idea is to streamline processes to reduce inputs and environmental impact. Finally, Drucker mentioned the transformation of social problems on paying jobs and therefore generating wealth. The above is similar to the third level of shared value creation, which establishes the development of local clusters, helping to generate local employment and improve the organizational context of the company.

At the beginning of the ninety's decade, Carroll (1991) developed his pyramidal model of corporate social performance (see Figure 3) which is an evolution of prior work of the same author in 1979 in which he defined CSR as the sum of four basic responsibilities of a company: economic, legal, ethical and philanthropic. The pyramid suggests an order or hierarchy of priorities in CSR, based on the level of essentiality or priority, being the economic the most fundamental, since it is the raison d'etre of the company; followed by legal responsibility, which focuses on the straightness of the organization to follow the laws. Ethical responsibility has to do with the expected behavior of the company before society, although they are not explicit rules, a morally correct behavior is expected. And finally, the least responsibility in importance is the philanthropic category, which refers to the goodwill of companies. 


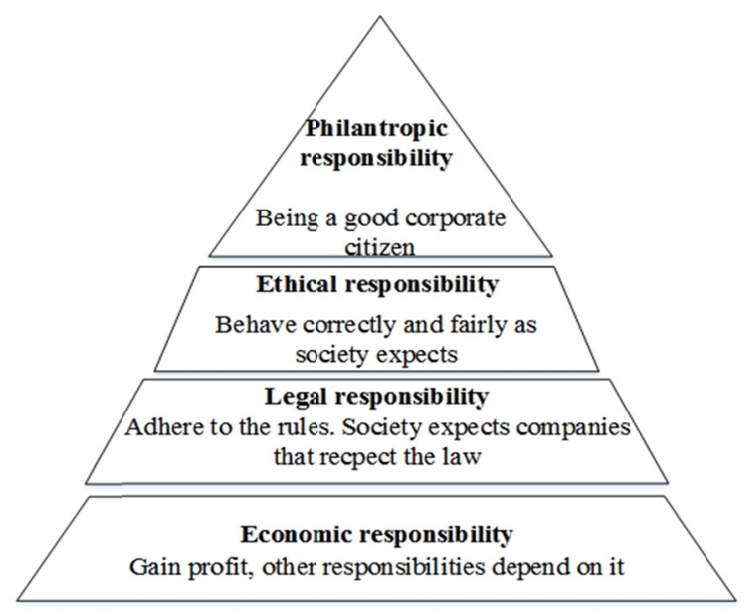

Figure 2. Pyramidal model of corporate social responsibility (Carroll, 1999)

Where to locate the creating shared value idea in Carroll's framework? You can see that the model is configured in a similar way to that proposed by the CDE (1971), only that in a pyramidal shape. Both models prioritize economic responsibility, which corresponds to the financial value as previously mentioned. In addition to this, the pyramid includes legal obligations, which could be linked to tax benefits for the government and obedience to labor laws, which would grant rights to workers. On the other hand, ethical responsibility translates into good practices for consumers (i.e. genuine advertising, product safety), suppliers (enforcing contracts), and competitors (fair competition). Finally, philanthropic responsibilities address aspects of social interest as environmentalists, special interest groups and local communities. That is, the model of CSR of Carroll (1991) implicitly seeks to respond to several of the interest groups, and assuming that this was undertaken it would be creating shared value.

In the early XXI century, Jensen's contribution (2000) established a criterion of maximizing value as the criteria for prioritizing stakeholders by the organization. Similar to the vision of Levitt (1958) and Friedman (1970), the author proposed to the companies to be interested in the social aspects if they were profitable. According to Garriga and Mele (2004) Jensen accepted the integration of some social demands some to the companies provided that they were profitable in the long run.

As the CSR literature developed, concepts linked to it such as sustainability, business ethics, corporate citizenship, strategic philanthropy, to name a few, emerged. It is partly for this situation protruding prospects for strategic corporate social responsibility; in which signals shared value can be located. For example, Lantos (2001) argues that strategic CSR is done to achieve business goals because good deeds are believed to be good for business and for society.

Following Milliman, Ferguson and Sylvester (2008) the strategic approach to CSR is particularly important because it creates social and economic benefits at the same time it is designed to produce profits and social benefits rather than profit or social benefits alone.

Werner (2009) cited by Afrin (2013) argues that strategic CSR is increasingly integrated into business operations and that when it is properly designed and implemented to suit the needs of the community and society, it may become a source of opportunities, innovation and competitive advantage.

An additional theoretical framework located in the literature of CSR is the one of Aras and Crowther (2009) by which the authors claim that four actions are necessary to achieve sustainable development: (a) maintaining economic activity, since this is the fundamental objective of any company; (b) conservation of the environment, since it is essential for the maintenance of future generations; (c) ensure social justice, which includes the elimination of poverty and (d) the guarantee of human rights; and development of cultural values, through which the company values align with individuals (see Figure 4). 


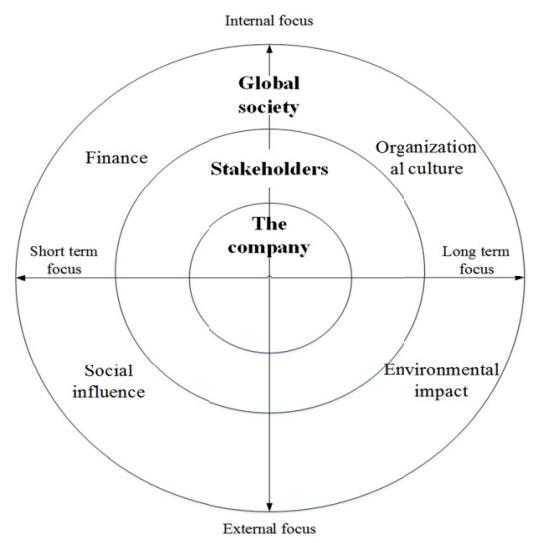

Figure 3. Model of sustainable development (Aras \& Crowther, 2009)

The authors argue that sustainability is beneficial not only for the environment but also for the organization because it cannot operate in the future without the resources of the present. Using the analogy of shared value, Aras and Crowther (2009) propose that for a company to obtain economic value, it must give value to the environment, which includes the establishment of an organizational culture to spread corporate values, as well as a positive social influence to give legitimacy to the actions taken to its stakeholders as these could affect the financial resources for the company tomorrow (Barnett, 2007).

\section{Conclusions}

According to the results of this documentary research, it is possible that the general idea behind of the creating shared value model, that is mutual benefit between business and society, had been suggested previously in the CSR literature. However, a possible explanation for the similarities in the contributions is the so-called variegation view of the CSR literature. According to Bakker, Groenewegen and Den Hond (2005), this approach argues that the progress of literature CSR has been diminished because of the emergence of "derived concepts" specialized in areas related to social responsibility or that even pretend to improve the previous concepts.

Under the variegation view, Mohan (as cited in De Bakker, Groenewegen, \& Den Hond, 2005) believes that CSR as a concept, refers to one or more interpretations of society-company relationship. For this reason, it is a concept that refers to social responsibility, but sometimes competes with others like business ethics, sustainable development, corporate philanthropy or organizational citizenship. Then it might be considered that creating shared value is one of these concepts that are added to the literature of CSR but which can overlap with other concepts inherent in the literature (see Figure 5).

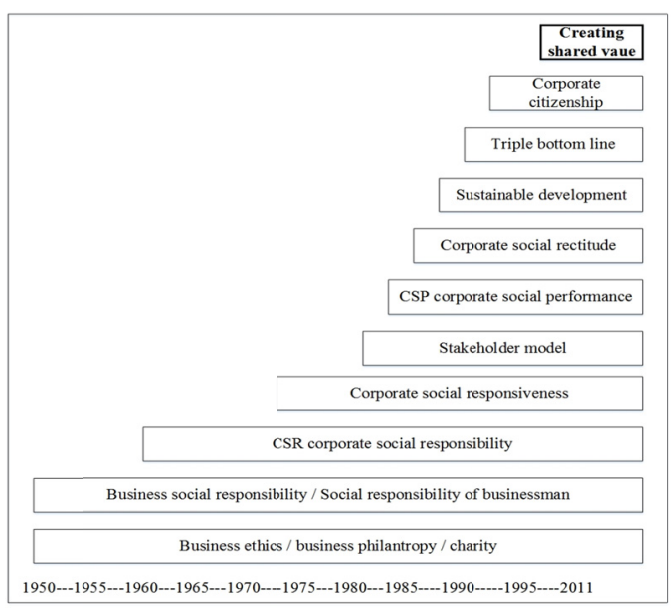

Figure 4. Development of concepts derived from CSR (De Bakker, Groenewegen \& Den, 2005)

This article had as objective to provide theoretical evidence from the literature of corporate social responsibility in relation to the debate on the originality of the proposal to creating shared value concept. This required a 
documentary inquiry and the analysis of theoretical contributions previous to the year of publication Porter and Kramer (2011) model, starting from the date beginning of modern literature CRS in 1953.

The results of this research can be considered consistent with Crane, Palazzo, Spence and Matten (2014) as evidence of theoretical perspectives that implicitly suggested the so-called win-win relationship between business and society was found. More specifically, it is possible that the ideas on which the shared value concept is based on were heavily influenced by those of Peter Drucker (1984) since his vision of CSR is similar to that intended by the creating shared value. It is this author's ideas in which the three levels of shared value creation could be inferred.

However, in favor of Porter and Kramer the results from the literature review did not provide evidence of a model that specifically indicates how to create joint value between companies and society, which the authors did claim. The findings indicate that a lot of the CSR literature proposed postures and some guidelines, but not as specific as the work of Porter and Kramer (2011).

In addition to the above, it must be taken into account that this analysis faced limitations. First, literature was sought only on the construct corporate social responsibility (CSR) overlooking a more thorough search of the concepts related to it as sustainability, corporate social performance, corporate social responsiveness, business ethics, corporate citizenship, strategic philanthropy, cause-related marketing. Reviewing the literature of each of the above topics is recommended for future studies that seek to supplement this investigation.

Secondly, another limitation resides in that the analysis focused on highlighting the contributions that could be interpreted in a way that relation with the central idea of shared value was found, however that interpretation should not be considered as the only possible one.

Finally, an additional constraint identified was the non-inclusion of literature in other languages but English. It was decided to consider the most relevant authors in the area of CSR since its inception in the modern era, with most of this works are written in English and published in journals of the same language (De Bakker et al., 2005; Ferreira-Mainardi \& Moran Suarez, 2011). Given the above, it is suggested to consider future research works in languages other than English to cover a larger volume of perspectives on corporate social responsibility.

\section{References}

Aakhus, M., \& Bzdak, M. (2012). Revisiting the role of "shared value" in the business-society relationship. Business and Professional Ethics Journal, 31(2), 231-246. http://dx.doi.org/10.5840/bpej201231211

Afrin, S. (2013). Traditional Vs Strategic Corporate Social Responsibility: In pursuit of supporting Sustainable Development. Journal of Economics and Sustainable Development, 4(20), 153-157.

Aras, G., \& Crowther, D. (2009). The Durable Corporation: Strategies for Sustainable Development. Gower.

Baraka, D. (2010). Corporations and the third sector: Responsible marriages at last? Journal of Global Responsibility, 1(1), 34-54. http://dx.doi.org/10.1108/20412561011038538

Barnett, M. L. (2007). Stakeholder Influence Capacity and the Variability of Financial Returns to Corporate Social Responsibility. The Academy of Management Review, 32(3), 794-816. http://dx.doi.org/10.5465/AMR.2007.25275520

Beschorner, T., \& Hajduk, T. (2015). Creating Shared Value: Eine Grundsatzkritik/Creating Shared Value: A Fundamental Critique. Zeitschrift Für Wirtschafts-Und Unternehmensethik. Mering: Rainer Hampp Verlag.

Bosch-Badia, M. T., Montllor-Serrats, J., \& Tarrazon, M. A. (2013). Corporate Social Responsibility from Friedman to Porter and Kramer. Theoretical Economics Letters, 3(3A), 11-15. http://dx.doi.org/0.4236/tel.2013.33A003

Bowen, H. R. (1953). Social responsibility of the businessman. New York: Harper.

Brown, D., \& Knudsen, J. S. (2012). No Shortcuts: Achieving Shared Value Means Changing Your Business Culture. http://doi.org/10.2139/ssrn.2179926

Bryson, J. M. (1995). Strategic Planning for Public and Nonprofit Organizations: A Guide to Strengthening and Sustaining Organizational Achievement (2nd ed.). Jossey-Bass Publishers.

Burke, L., \& Logsdon, J. M. (1996). How corporate social responsibility pays off. Long Range Planning, 29(4), 495-502. http://dx.doi.org/10.1016/0024-6301(96)00041-6

Carroll, A. B. (1979). A three-dimensional conceptual model of corporate performance. Academy of Management Review, 4(4), 497-505. http://dx.doi.org/10.5465/AMR.1979.4498296 
Carroll, A. B. (1991). The pyramid of corporate social responsibility: Toward the moral management of $\begin{array}{llll}\text { organizational } \quad \text { stakeholders. } & \text { Business } & \text { Horizons, } & 34(4),\end{array}$ http://dx.doi.org/10.1016/0007-6813(91)90005-G

Carroll, A. B. (1999). Corporate social responsibility evolution of a definitional construct. Business \& Society, 38(3), 268-295. http://dx.doi.org/10.1177/000765039903800303

Carroll, A. B. (2008). A history of corporate social responsibility: Concepts and practices. The Oxford Handbook of Corporate Social Responsibility, 19-46. http://dx.doi.org/10.1093/oxfordhb/9780199211593.003.0002

Carroll, A. B., \& Shabana, K. M. (2010). The business case for corporate social responsibility: A review of concepts, research and practice. International Journal of Management Reviews, 12(1), 85-105. http://dx.doi.org/10.1111/j.1468-2370.2009.00275.x

Clarkson, M. E. (1995). A stakeholder framework for analyzing and evaluating corporate social performance. Academy of Management Review, 20(1), 92-117. http://dx.doi.org/10.5465/AMR.1995.9503271994

Corsaro, D. (2014). The emergent role of value representation in managing business relationships. Industrial Marketing Management, 43(6), 985-995. http://dx.doi.org/10.1016/j.indmarman.2014.05.011

Crane, A., Palazzo, G., Spence, L. J., \& Matten, D. (2014). Contesting the value of "creating shared value". California Management Review, 56(2), 130-153. http://dx.doi.org/10.1525/cmr.2014.56.2.130

Dahlsrud, A. (2008). How corporate social responsibility is defined: An analysis of 37 definitions. Corporate Social Responsibility and Environmental Management, 15(1), 1-13. http://dx.doi.org/10.1002/csr.132

De Bakker, F. G. A., Groenewegen, P., \& Den Hond, F. (2005). A bibliometric analysis of 30 years of research and theory on corporate social responsibility and corporate social performance. Business \& Society, 44(3), 283-317. http://dx.doi.org/10.1177/0007650305278086

Dembek, K., Singh, P., \& Bhakoo, V. (2015). Literature Review of Shared Value: A Theoretical Concept or a Management Buzzword? Journal of Business Ethics, 1-37. http://doi.org/10.1007/s10551-015-2554-z

Denning, S. (2011). Why "shared value" can't fix capitalism. Forbes. Retrieved from http:/sites/stevedenning/2011/12/20/why-shared-value-cantfix-capitalism/

Donaldson, T. (2014). Shared values that are lost in translation. Financial Times. Retrieved from http://www.ft.com/intl/cms/s/2/bfdfff94-b34c-11e3-b09d-00144feabdc0.html\#axzz3O9BYyPm5

Drucker, P. F. (1984). Converting Social Problems into Business Opportunities: The New Meaning of Corporate Social-Responsibility. California Management Review, 26(2), 53-63. http://dx.doi.org/10.2307/41165066

Dubois, C. L. Z., \& Dubois, D. A. (2012). Expanding the Vision of Industrial-Organizational Psychology Contributions to Environmental Sustainability. Industrial and Organizational Psychology, 5(4), 480-483. http://dx.doi.org/10.1111/j.1754-9434.2012.01482.x

Dyllick, T. (2014). The opposing perspectives on creating shared value. Financial Times. Retrieved from http://www.ft.com/cms/s/2/88013970-b34d-11e3-b09d-00144feabdc0.html\#axzz33cvuxOQI

Eden, C., \& Ackermann, F. (1998). Making Strategy: The Journey of Strategic Management. SAGE.

Epstein-Reeves, J. (2012). What is "Creating Shared Value"? Forbes. Retrieved from $\mathrm{http} / /$ www.forbes.com/sites/csr/2012/06/04/what-is-creating-shared-value/\#5a05b43d5c40

Ferreira-Mainardi, C., \& Morán-Suárez, M. A. (2011). La responsabilidad social corporativa (RSC) en las bases de datos Scopus y Wos (estudio bibliométrico). EDICIC, 1(4), 141-160.

Frederick, W. C. (1960). The Growing Concern over Business Responsibility. California Management Review, 2(4), 54-61. http://dx.doi.org/10.2307/41165405

Frederick, W. C. (2006). Corporation, be good!: the story of corporate social responsibility. Indianapolis: Dog Ear Publishing.

Freeman, R. E. (1984). Strategic Management: A Stakeholder Approach. Boston: Pitman.

Friedman, M. (1970). The social responsibility of business is to increase its profits. The New York Times Magazine.

Garriga, E., \& Melé, D. (2004). Corporate social responsibility theories: Mapping the territory. Journal of Business Ethics, 53(1-2), 51-71. http://dx.doi.org/10.1023/B:BUSI.0000039399.90587.34

Heald, M. (1970). The social responsibilities of business: Company and community 1900-1960. Transaction 
Publishers.

Holmes, S. L. (1976). Executive perceptions of corporate social responsibility. Greenwich: Elsevier Inc. http://doi.org/10.1016/0007-6813(76)90049-5

Husted, B. W. (2015). Corporate Social Responsibility Practice from 1800-1914: Past Initiatives and Current Debates. Business Ethics Quarterly, 25(1), 125-141. http://dx.doi.org/10.1017/beq.2014.1

Jensen, M. C. (2000). Value maximization and the corporate objective function. In N. Beer, M and Nohria (Ed.), Breaking the Code of Change (pp. 37-57).

Johnson, H. L. (1971). Business in contemporary society: Framework and issues. Wadsworth Pub. Co.

Jones, T. M. (1980). Corporate Social Responsibility Revisited, Redefined. California Management Review, 22(3), 59-67. http://dx.doi.org/10.2307/41164877

Lantos, G. P. (2001). The boundaries of strategic corporate social responsibility. Journal of Consumer Marketing, 18(7), 595-632. http://dx.doi.org/10.1108/07363760110410281

Levitt, T. (1958). The Dangers of Social-Responsibility. Harvard Business Review, 36(5), 41-50.

Lewis, D. L. (1976). The public image of Henry Ford: An American folk hero and his company. Wayne State University Press.

Maltz, E., \& Schein, S. (2012). Cultivating Shared Value Initiatives: A Three Cs Approach. Journal of Corporate Citizenship, (47), 55-74. http://dx.doi.org/10.9774/GLEAF.4700.2012.au.00005

Maltz, E., Thompson, F., \& Ringold, D. J. (2011). Assessing and maximizing corporate social initiatives: A strategic view of corporate social responsibility. Journal of Public Affairs, 11(4), 344-352. http://dx.doi.org/10.1002/pa.384

Margolis, J. D., Elfenbein, H. A., \& Walsh, J. P. (2007). Does it pay to be good? A meta-analysis and redirection of research on the relationship between corporate social and financial performance. Ann Arbor, 1001, 41234-48109.

McGuire, J. W. (1963). Business and Society (Vol. 144). New York: McGraw-Hill.

Milliman, J., Ferguson, J., \& Sylvester, K. (2008). Implementation of Michael Porter's Strategic Corporate Social Responsibility Model. Journal of Global Business Issues, 29.

Mitchell, R. K., Agle, B. R., \& Wood, D. J. (1997). Toward a theory of stakeholder identification and salience: Defining the principle of who and what really counts. Academy of Management Review, 22(4), 853-886.

Moon, H. C., Pare, J., Yim, S. H., \& Park, N. (2011). An extension of Porter and Kramer's creating shared value (CSV): Reorienting strategies and seeking international cooperation. Journal of International and Area Studies, 49-64.

Moura-Leite, R. C., \& Padgett, R. C. (2011). Historical background of corporate social responsibility. Social Responsibility Journal, 7(4), 528-539. http://dx.doi.org/10.1108/1747111111117511

Nutt, P. C., \& Backoff, R. W. (1992). Strategic management of public and third sector organizations: A handbook for leaders. Jossey-Bass.

Pirson, M. (2012). Social entrepreneurs as the paragons of shared value creation? A critical perspective. Social Enterprise Journal, 8(1), 31-48. http://dx.doi.org/10.1108/17508611211226575

Porter, M. E., \& Kramer, M. R. (2011). The big idea: Creating shared value. Harvard Business Review, 89(1/2), 62-77.

Porter, M. E., \& Kramer, M. R. (2014). A response to Andrew Crane et al.'s article by Michael E. Porter and Mark R. Kramer. California Management Review, 56(2), 149-151.

Porter, M., Hills, G., Pfitzer, M., Patscheke, S., \& Hawkins, E. (2012). Measuring shared value: How to unlock value by linking social and business results. FSG. Creative Commons Attribution.

Prahalad, C. K., \& Ramaswamy, V. (2000). Co-opting customer competence. Harvard Business Review, 78(1), 79-90.

Scholes, K., \& Johnson, G. (2002). Exploring corporate strategy. Prentice Hall International.

Schumpeter, R. (2011). Oh, Mr Porter-The new big idea from business's greatest living guru seems a bit undercooked. The Economist. Retrieved from http://www.economist.com/node/18330445 
Shrivastava, P., \& Kennelly, J. J. (2013). Sustainability and Place-Based Enterprise. Organization \& Environment. http://dx.doi.org/10.1177/1086026612475068

Steiner, G. A. (1971). Business and society. New York: Random House Inc.

Verboven, H. (2011). Communicating CSR and business identity in the chemical industry through mission slogans. Business Communication Quarterly, 74(4), 415-431. http://dx.doi.org/10.1177/1080569911424485

Wang, S. (2015). Chinese Strategic Decision-making on CSR. Springer-Verlag Berlin Heidelberg. http://dx.doi.org/10.1007/978-3-662-44997-4

\section{Copyrights}

Copyright for this article is retained by the author(s), with first publication rights granted to the journal.

This is an open-access article distributed under the terms and conditions of the Creative Commons Attribution license (http://creativecommons.org/licenses/by/4.0/). 